\title{
4. Description of some new Lepidoptera from Sikkim.
} By H. J. Euwes, F.Z.S.

[Received May 3, 1887.]

The species described in this short paper are from a large collection made by myself in the rainy season of 1886 , whilst waiting at Darjiling for the departure of the Tibet Mission. They will be included in a Catalogue of the Lepidoptera of Sikkim, of which I have nearly completed the first part containing the Rhopalocera, and, taken in connection with those now described by Mr. De Nicéville, prove that, notwithstanding the great activity which has been shown by Messrs. O. Möller, De Nicéville, and Knyvett in that country, its very long list of Butterfiles is not yet complete.

I hope to be able to give figures of the new species in my Catalugue of the Lepidoptera of Sikkim.

\section{Lethe tristigmata, n. sp.}

This very distinct insect, of which the male sex only is known, had been already distinguished by Möller in 1885 as a new species, and was described by Mir. De Nicéville in MS. ; but as I found it in 1386 myself and was about to publish it under the present name, Mr. De Nicéville has kindly allowed me to transfer the description (which I give below) to my own paper. I took it on Tonglo, from about 8500 to 9500 feet, in $\mathrm{July}$, when most of the specimens were no longer fresh; but its time of appearance is in June. It frequents open spots in the bamboo-jungle and low dripping forest, and settles on the path like other species of Lethe. Though I searched carefully I never saw a female: this sex probably remains concealed in the thick foliage, in these forests often too dense to allow one to go off the path; and I found here, as elsewhere, that a good open path is even more essential to success in collecting forest Butterflies than it is for plants or birds.

MALE. UPPERSIDE: both wings brown, with a golden gloss in certain positions. Fore wing with the bar towards the end of the cell and the dorsal band of the underside showing through by transparency; a submarginal series of five small round ochreous spots or dots from the costa to the second median interspace; a diffused and indistinct marginal dark band, its outer edge somewhat sharply defined. Hind wing with a dark bar defining the discocellular nervules, and an obscure discal irregular band; a submarginal series of round, equal-sized, somewhat small, black spots, those towards the anal angle sometimes absent; two fine dark marginal lines enclosing an obscure ochreous line, the inner dark line defined inwardly by a pale line.

UNDERSIDE: both wings paler, being ochreous brown without any gloss. Fore wing with two darker bars crossing the cell beyond 
its middle, enclosing a paler space; a discal irregular dark band, with its inner edge diffused, its outer edge sharply defined, its direction from the costa to the first median nervule straight, then directed inwardly to the submedian nervule, the ground beyond this band paler than the rest of the wing; the submarginal subapical dots as above but violet-white; a very fine violet-white line, then a broad ochreous line, then a fine dark line on the margin. Hind wing with an oval ring-spot at the base of the costal interspace, a band in continuation across the cell, another band beyond from the costal to the median nervure towards the end of the cell, dark brown, outwardly pale ochreous, and very straight; a short irregular band from just before the base of the first median nervule towards the abdominal margin; a highly irregular discal band, its outer edge sharply defined, its inner edge diffused; beyond which is a series of six ocelli, composed of a black centre with a violet-white pupil, an ochreous, a dark brown, and a violet ring, the latter ring widest outwardly, the sixth ocellus at the anal angle geminated; a fine marginal violet line, expanding into lunules at the anal angle, two fine dark lines beyond the violet line enclosing an ochreous broad line.

Lethe tristigmata is nearest to $L$. nicetas, Hewitson; but the male is at once distinguished from that species in possessing a very conspicuous "male mark" on the upperside of the fore wing just beyond the cell, which is composed of more or less wedge-shaped clumps of large black scales, placed one below the third median nervule, one on each side of the second and first median nervules, and one above the submedian nervure, these marks sometimes coalescing and forming a continuous band divided only by the veins.

Expanse $2 \cdot 3$ inches.

\section{Zophoessa mölLeri, $\mathrm{n}$. $\mathrm{sp}$.}

This species is very nearly allied to $Z$. jalaurida, de Nicév., but differs constantly in the following particulars. The tawny bands and markings of the upperside are paler and less defined. Beneath, the ocelli of the fore wing are absent, the ground-colour is paler, the silvery bands are straighter and broader, and in the outer one, which is broadest, the discocellular nervule which it encloses is distinctly marked by a brown streak in the silver band, which is free and not connected with the brown band next the silver as in Z. jalaurida. I found this species mixed with jalaurida, but not so abundant or reaching so high an elevation, on the Singalelah range, and did not at first recognize its distinctions, which Möller afterwards noticed. After comparing 12 fresh specimens with 10 perfectly fresh males and 6 females of $Z$. jalaurida taken with it, and one from the Jalauri Pass, I have no hesitation in saying that it is a perfectly distinct species, and have much pleasure in naming it after Mr. Möller. The two sexes are nearly alike, but the females, of which I only took two, are a trifle larger and paler than the males. 
Chilades? pontis ${ }^{1}$, n. sp.

Male above dull purplish black with faint green or (in some lights) purple reflection, darker towards the body. Fringes alternated with black and white.

Beneath dull grey, with irregular darker markings, which on the hind wing coalesce into a blackish patch powdered with grey on the inner half of the wing.

Body black, with grey hairs and palpi. Antennæ faintly ringed, with a short distinct club.

Expanse $\frac{9}{10}$ inch.

The shape of the hind wing is very peculiar, the costal margin, which is straight, forming almost a right angle with the outer margin. I know of no other species in which the character is so well marked.

Described from three males (a fourth exists in Godman's collection ex coll. Lidderdale) taken by me on May 27, 1886, on the bridge crossing the Rangbi river on the way from Darjeeling to Mongpo, at about 6000 feet elevation, in dense dripping evergreen-forest.

This curious little insect is unlike anything found in India or the Himalaya, but has a very near ally in China, which, as it is undescribed, I will here characterize as follows :-

\section{Chilades sinensis, n. $\mathrm{sp}$.}

Resembles $C$. pontis, but has a broad border of darker colour than the wings, no green reflections, and a rounder apex to the fore wing. Beneath, the markings are very similar but more continuous, and there is an outer band near the margin of the fore wing not found in $C$. pontis. The dark markings on the hind wing also come nearer to the margin.

Described from a specimen taken by Mr. H. Leech near Ningpo in May 1886. This agrees perfectly with several others from Kiukiang on the Yangtse river taken by Maries, which have for some years been in the collection of the British Museum.

\section{Hypolycena virgo, n. sp.}

Female. Fore wing above black, with a large discal patch of Frenchgrey extending to the hind margin inwardly. Hind wing grey powdered with black, and becoming dull black on the costal margin, with a single narrow black tail tipped white, and a small fuscous lobe at anal angle. Finges white, narrow towards the apex of fore wing.

Beneath bright French-grey, with a distinct transverse sinuous yellowish band, narrowly edged black on both sides about two thirds of the length, not extending quite to the hinder margin; a short

${ }^{1}$ I include this in the genus Chilades (Moore, Lep. Ceylon, i. p. 71) with doubt. It seems, on a superficial examination, to have most affinity to Chilades laius, Cram.; but without sacrificing a specimen I cannot be sure that the apparent resemblance is real. And many of Moore's distinctions are so trivial that I do not think they can be adopted without an independent study, not only of the insects in question, but of the whole of the Eastern Lycænidæ. 
double-lined bar at the end of the cell and an indistinct outer band near the edge. Hind wing with similar bands, of which the first extends in the usual broken $\mathrm{W}$ to the inner margin, and in addition a short band of three blackish spots within the discal bar; at the anal angle two blue spots, of which the outer is half black. Antennæ ringed black and white, with a fuscous tip to the club. Body above black, with grey hairs; pale grey beneath.

Expanse $1 \cdot 4$ inch.

Described from a single perfectly fresh female, which I took on May 27 in the same place as Chilades pontis. Though I visited the spot on several occasions, I never saw another, and the male will probably be found earlier in the season.

Notwithstanding the very numerous species of this group of Lycænidæ which have been described from Sikkim, I think this is so well distinguished by the pattern of the underside that it cannot be the female of any known species.

\section{Saturnia royi, n. sp.}

Male. Above deep chocolate-brown, with a darker band running from near the apex parallel to the margin of fore and hind wings. The upper half of the hind wings grey, with an ocellus in the centre composed of a small grey pupil, a broad ring of black, a narrow ring of grey, and another narrow black ring, the whole being surrounded by a dark circle which coalesces with the band crossing the wing. In the fore wing is a round membranous but not transparent patch at the end of the cell about two lines in diameter; close to the apex is a triangular patch of grey scales, a few of which are continued in a sinuous line across the fore wing parallel to the margin.

Beneath, the whole surface is chocolate-brown, with the band as above, powdered throughout with grey scales, which take the form of a downy fur towards the inner part and are longest on the discal area. The pupil only of the ocellus shows on the under surface, and the margin is free from grey powdering. Antennæ broadly pectinated. Thorax covered with long chocolate hair, yellowish behind the head. Breast covered with long rusty fur; tarsi grey outside.

Expanse nearly 5 inches.

Described from a fresh specimen, one of three which were taken on Tonglo near Darjeeling, at an elevation of 10,000 feet, by Babu Dewan Roy, a Nepalese in the service of the Forest Department, after whom I name this beautiful and distinct species, as a recognition of the interest he has shown in the natural history of his district, and of the great assistance he has rendered me in collecting insects there. 


\section{$2 \mathrm{BHL}$ Biodiversity Heritage Library}

Elwes, Henry John. 1887. "4. Description of some new Lepidoptera from Sikkim." Proceedings of the Zoological Society of London 1887, 444-447. https://doi.org/10.1111/j.1096-3642.1887.tb02987.x.

View This Item Online: https://www.biodiversitylibrary.org/item/99199

DOI: https://doi.org/10.1111/j.1096-3642.1887.tb02987.x

Permalink: https://www.biodiversitylibrary.org/partpdf/73014

\section{Holding Institution}

Natural History Museum Library, London

\section{Sponsored by}

Natural History Museum Library, London

\section{Copyright \& Reuse}

Copyright Status: Public domain. The BHL considers that this work is no longer under copyright protection.

This document was created from content at the Biodiversity Heritage Library, the world's largest open access digital library for biodiversity literature and archives. Visit BHL at https://www.biodiversitylibrary.org. 